\title{
Switzerland balks at opening research funds
}

Basel \& Munich. Switzerland has been told that it can participate in the European Union (EU) fourth Framework research programme provided that it agrees on a package of political demands from the union - and opens up some of its own national research programmes to scientists in EU states.

But the EU research ministers have held back from offering the same deal to Israel on the grounds that, unlike Switzerland, it lies outside the European continent, and is therefore not eligible for EU membership.

The ECU12 billion (US\$13.6 billion) Framework programme, which runs from 1995 to 1999 , is designed partly to stimulate European competitiveness by supporting research that underpins the future needs of

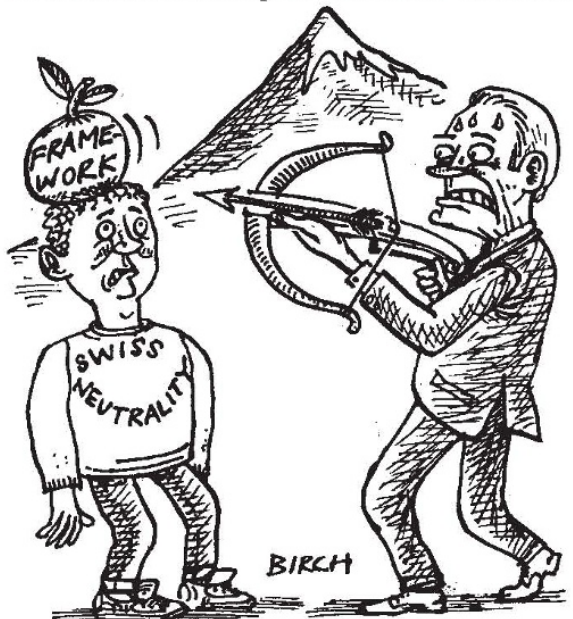

industry. Some EU countries argue that this goal could be endangered if the programme is opened up to non-European states.

The Swiss population has consistently rejected all suggestions that Switzerland should join the EU. But the government, reflecting the view of its industrial community, is still keen that it should participate in Framework, and has made such a request to Brussels.

A final decision will depend on the outcome of separate negotiations over the next six months on Switzerland's adherence to certain EU principles, including freedom of commercial traffic through the Alps (which Switzerland has voted to confine to rail within 10 years), and the freedom of $\mathrm{EU}$ citizens to live and work in Switzerland.

If these negotiations are successful, and Switzerland is subsequently accepted into Framework, it will have to contribute ECU375 million to the programme over five years. Bruno Spinner, a member of the Swiss delegation responsible for EU negotiations, says the money will be well spent. "A considerable amount of money will flow back into Switzerland as a result of participation," he adds, in a bid to reassure critics who argue that the contribution will be taken out of the science budget (see Nature 369, 264; 1994).
But science administrators in Switzerland are worried about a demand from the EU research ministers that, in return - and to ensure a reciprocal exchange of scientific results between the EU and Switzerland the country should open up its own 'equivalent' national programmes to grant applications from scientists in other EU countries.

A spokesman for the Swiss foreign ministry points out that the national science funding agencies in EU member states are not required to do this, and describes the demand as "surprising". Hans Peter Hertig, general secretary of the Swiss National Science Foundation (SNF), goes further, and says that the condition is "unacceptable".

In response to such concerns, commission officials concede that it may be necessary to negotiate a compromise. One possible solution could be to identify specific research programmes, perhaps part- funded by industry, that would be opened up to wider participation. The SNF, which supports basic research, would continue to fund Swiss researchers only.

Israel's request for similar full participation in the Framework programme was rejected by the council of research ministers at a meeting last month because some EU countries, in particular France, feared that such participation would set an undesirable precedent for other non-European countries.

But Israel, backed by the commission itself, is still hoping to persuade the ministers to change their minds. Marcel Shaton, from the Israeli embassy in Brussels, says that the high standard of science in Israel means that participation would be of mutual benefit. He also says that it would help to promote good industrial relations between Israel and Europe.

Oliver Klaffke \& Alison Abbott

\section{UK bans use of fetal eggs in IVF}

London. Britain's Human Fertilization and Embryology Authority (HFEA) announced last week that it will not allow immature oocytes or ovarian tissue from aborted fetuses or cadavers to be used in the treatment of infertile women.

But it has agreed that such tissue can be used for research. It also said that it is prepared to approve the use of ovarian tissue from adult cadavers for treatment "in principle", but will do so in practice only when wider issues about consent have been investigated further.

The HFEA's decision comes after a sixmonth consultation period during which the body, set up by the government almost four years ago to regulate both research on and the application of fertilization treatment, received nearly 10,000 responses.

Sir Colin Campbell, chairman of the HFEA, said last week that its main concerns about the use of fetal ovarian tissue for treatment were the possible effects on the recipient mother, the strength of public opposition ( 83.2 per cent of respondents were against it), the unknown psychological effects on a child born in this way, and lack of knowledge of the development of fetal eggs.

But Campbell added that he was optimistic that the need for the technology, which is still 10-20 years away from being feasible in humans, would be reduced or eliminated by the development of other methods of fertilization. The two areas considered most promising are to take pieces of ovarian tissue from volunteers and mature the oocytes in vitro, or to transplant the donated ovarian tissue into infertile women where the eggs could mature naturally.

Research using fetal ovarian tissue will be licensed by the authority, subject to existing controls, including the need for informed consent to the use of the tissue for research.

Almost 60 per cent of respondents were opposed to this. But Campbell said that research could do much to alleviate disease, improve processes for fertility treatment. and prevent the passing on of inherited diseases, and because "ultimately you can't stop research". He added later that even if public opposition meant that this research was banned in the United Kingdom, it would be carried out elsewhere in the world.

The HFEA's conclusions effectively coincide with an amendment pushed through the House of Commons in April by Dame Jill Knight, Conservative member of parliament for Birmingham-Edgbaston, which stated that fetal germ cells should not be used "for the purposes of providing fertility services for any woman".

A second attempt by Lord Walton to overturn the ban had failed in the House of Lords the previous week, after help previously offered by the government to reword an earlier amendment in a more acceptable form had failed to materialize.

Commenting on the parliamentary moves, Campbell said, in the context of the HFEA's advice, Knight's amendment was "quite redundant".

The legislation does not differ from the HFEA's recommendations in what it prohibits. But Richard Gardner of Oxford University, who chaired a working group which prepared a response to the HFEA on behalf of the Royal Society, criticizes the fact that Knight introduced her amendment before the consultation process had run its course.

Maggie Verrall 